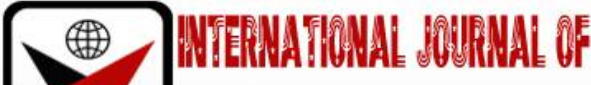

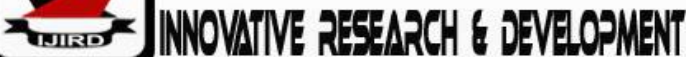

ISSN 2278 - 0211 (Online)

\section{A Functional Penitentiary Institution in Nigeria Criminal Justice System: An Antidote to Recidivism}

Alaba Ibironke Kekere
Lecturer, Department of Private Law,
Adekunle Ajasin University, Akungba-Akoko, Ondo State, Nigeria

\begin{abstract}
:
In contemporary times, recidivism has been on high increase in the Nigerian society. The reason is not far-fetched, as the correctional institution which is saddled with the responsibility to reform, rehabilitate and re-integrate criminals into the society has failed in performing its role effectively. A lot of factors are responsible for recidivism in Nigeria. Corruption among the prison officials oftentimes results in prison swop and even jail breaks. Funds meant for feeding, health care and training of prison inmates are embezzled by the officials, thus making prisoners pass through dehumanizing conditions, and their fundamental human rights violated. This eventually makes them hardened criminals after serving their jail term, against the primary role of reform and rehabilitation by the prison. In view of this, the role of a functional penitentiary institution cannot be over-emphasized in a nation where peace and security are the ultimate goal. Hence, the time is now for government to put in place policies that will guarantee the reformation and rehabilitation of inmates so as to curb the menace of recidivism. Therefore, this paper supports and contributes to the body of existing knowledge on recidivism in Nigeria and concludes that this framework will serve as a tool for combating the menace of recidivism in the country and serve as impetus for national growth.
\end{abstract}

Keywords: Prisoners, recidivism, criminal justice administration

\section{Introduction}

The Nigerian prison system has witnessed an enormous increase in people relapsing into crime and criminality. ${ }^{i}$ Accordingly, the thrust of this article delves into issues pertinent to recidivism as it borders on criminal justice system. The phrase 'criminal justice system' is a system of practices and institutions of government directed at upholding social control, deterring and mitigating crime, or sanctioning those who violate law with criminal penalties and rehabilitation efforts.ii One of the most concise definitions of criminal justice is that which describes it as the collective institutions which an accused offender passes until the accusations have been disposed of or the assessed punishment is concluded iii To be precise, criminal justice system is all about the agencies of government that are charged with implementing the law and, judging criminals and modifying criminal conducts. ${ }^{\text {iv }}$ Thus, it involves basically arrest, booking, trial and confinement. Once a crime is reported to the police, investigations begin, witnesses are interrogated, the accused is taken before a competent court for trial process, and the outcome is whether conviction or acquittal. ${ }^{\mathrm{v}}$

The major components of criminal justice system in Nigeria are the police, prosecutor, judiciary (criminal court divisions) and correctional institutions, which include the prisons, bostal homes and remand homes. ${ }^{\text {vi }}$ It is suffice to say that a country that successfully gets its criminals reformed and rehabilitated has effectively addressed a great part of its governance concerns because of the centrality of the criminal justice system to order and stability.vii

\subsection{Conceptualization of Key Terms}

\subsubsection{Recidivism}

According to Black's law dictionary, recidivism is described as 'repetition of criminal behaviour'. viii Recidivism is the act of reengaging in criminal offence despite having been punished and released from prison. It involves who are rearrested, reconvicted or returned to custody within a specific time period. Also, it is defined as the relapse into crime of one once convicted and punished for a crime. ${ }^{\mathrm{ix}}$

Across the globe, the concept of recidivism has, over time been known by different vocabularies. Recidivism comprises re-arrest, resistance to rehabilitation, ${ }^{\mathrm{x}}$ repeat offending, ${ }^{\mathrm{xi}}$ re-conviction, re-offending, ${ }^{\mathrm{xii}}$ re-admission, reincarceration, repetitious criminal tendency etc. ${ }^{x i i i}$ In comprehensive terms, recidivism connotes a relapse into crime and criminal lifestyle or activities by an offender who had once or more times been processed through the penal system. ${ }^{x i v}$ Equally known as repeaters and offenders beyond rehabilitation, recidivists are persons who repeatedly violate the law, get arrested and processed by the criminal justice administrators. $\mathrm{xv}$ 


\subsubsection{Prison}

The Black's law dictionary described prison as 'a public building or other place for the confinement of persons, whether as a punishment imposed by the law or otherwise in the course of the administration of justice.'xviAccording to Prisons Act in Nigeria, a prison is defined as a place delineated and declared as such by the law of the state and created to ensure restraint and custody of individual accused or convicted of violating the criminal law of the state.xvii The law also states that:

- The Minister of Internal Affairs may by order in the federal gazette declare any building or place in Nigeria to be a prison and by the same or subsequent order specify the area for which the prison.

- Every prison shall include the grounds and buildings within the prison enclosure and any lock-up house for the temporary detention or custody of prisoners newly apprehended or under remand which is declared by the minister by order in the federal gazette to be part of the prison.xviii

Thus, the pronouncement(s) of the Minister of Interior as stated above can create a prison within the geopolitical entity called Nigeria. Consequently, a prison can be described as a place where offenders are kept as punishment for (a) crime(s) committed. ${ }^{\text {ix }}$ It also serves as a place where persons are kept while awaiting trial..x A prison is a place where people are being confined physically and usually underprivileged of a variety of freedoms.xi According to McCorkle and Korn, a prison is a physical structure in a geographical location where a number of people living under highly specialized condition adjust to the alternatives presented to them by the unique kind of social environment.xxii

\subsubsection{Prisoner}

According to Black's Law Dictionary, a prisoner is a person who has been convicted and is serving term in prison. ${ }^{x x i i i} \mathrm{~A}$ prisoner is defined as a person who is sent to the prison by a competent court for violating the laws of a place.xxiv According to Prisons Act, a prisoner is defined as any person lawfully committed to custody. ${ }^{\mathrm{xxv}}$ As a matter of fact, this means that if one is lawfully committed to prison custody, he or she is a prisoner.xxvi

\subsubsection{Imprisonment}

According to Criminal Procedure Act, the term imprisonment is described as a punishment for criminal offences and consists of the detention of the offender in a prison, imprisonment as a form of punishment is generally coupled with hard labour except if it is so specified by the circumstances of the case. ${ }^{\text {xxvii }}$

\subsection{Historical Background of the Nigerian Penitentiary System}

Historically, history reveals that the human race has made use of prisons over a long time.xxviii In fact, prisons have been in existence even before the advent of Christ in the Old Testament.xix Although, not a punishment in itself, it was rather a way to confine criminals until corporal or capital punishment.xx There were prisons used in Jerusalem in the Old Testament era, and the Holy Bible details the imprisonment of Joseph in Egypt when his brothers sold him into slavery. $x \times x i$ Upon arriving in Egypt, he had a master called Potiphar. The wife of Joseph's master reprehensibly and falsely accused Joseph of raping her. ${ }^{\text {xxxii }}$ As such, his master committed him to prison, a place where the King's prisoners were kept.xxxiii The story of Joseph marked the first example of prison in the earliest times. xxxiv However, today, it is accepted that a prison is part of the institutions for the actualization of punishment. ${ }^{\mathrm{xxv}}$ It also provides an avenue for the convicted or alleged criminal not only to be kept away from society but also for the state to rehabilitate the criminals.xxxvi At any rate, what is obtainable in the Nigerian Prisons is quite different from this theory. ${ }^{x x x v i i}$

As a matter of fact, previously and prior to the arrival of the British colonial rule, imprisonment was a part of precolonial Nigerian societies and there were clear propositions of functional equivalents of prisons. xxxviii The idea of imprisonment as a means of punishing offenders is neither alien to Nigeria nor new to many Nigerian societies.xxix Ever before the British colonial rule in Nigeria, the communities like many others had assumed the responsibility of putting away the defiant citizens and preventing such individuals from doing further harm.xl For example, among the pre-colonial societies such as the Yorubas, Tivs, Edos and Fulanis, there were proofs of the use of confinement and incarceration. xli

History of Nigeria's penal system confirms that there existed forms of imprisonment which were equivalent to prisons in the pre-colonial Nigeria where offenders remained locked up, and these prisons according to different tribes were called by several names. xlii In the Benin Kingdom, now the Edos, it was called Ewedo; xliii it was also called GidanYari by the Hausas in the Northern part of Nigeria and in most cases built at the back of their Emir's palace; ${ }^{x l i v}$ the Yorubas in the Western part of Nigeria called it Ewon.xlv Additionally, a place of confinement existed in Lagos named Faji where offenders were incarcerated. ${ }^{\text {lvi }}$ It is appropriate to mention that all these forms of prisons remain operative until the British introduced a modern prison in Lagos territory. xlvii

However, the current prison system in Nigeria today is a colonial creation.lviii In the history of penal institutions, prisons in Nigeria started with the British Government of Lagos Colony in 1861. ${ }^{\text {lix }}$ The penal system was based primarily on incarceration that was designed first, to protect the economic interests of local subsidiaries of British companies doing business in Nigeria.1 The idea of an organized prison system began in 1862 when Freeman was commissioned to appoint judges and other necessary officers. ${ }^{\text {li }}$ The creation of courts coupled with the appointment of a judge to man the court was a prerequisite for the establishment of a prison. ${ }^{\text {lii }}$ The British colonial masters opened the first prison in Nigeria in a place presently known as the broad street in Lagos State Nigeria, the prison which was intended to accommodate 300 prisoners and modeled on the British system. This marked the first time where trained officers were commissioned to man the penitentiary institutions in Nigeria. ${ }^{\text {liii }}$ 


\subsection{The Role and Functions of Penitentiary Institution in Nigeria's Criminal Justice System}

A general preview of previous legislation up until present reveals that the Nigerian Prison Service has the responsibility of confining a prisoner or a criminal prisoner. A criminal prisoner is defined as a person convicted of a crime and a prisoner is anyone lawfully committed to prison. The major aim of establishing the prison is to provide for reformation, rehabilitation as well as correctional facilities to those who have violated the laws of the society.

The Nigerian Prisons Actliv is the national instrument that provides the legal and institutional framework of the Nigerian prison system. Through this Act, the prison system is placed under the supervision of the Ministry of Internal Affairs. It is worthy of note that the Prison Act does not define or outline the functions of the Nigerian prisons. However, the Staff Duties Manual of the Nigerian Prisons Service (NPS) stipulates the functions of prison which include:

- Keeping safe custody of persons that are legally confined in prison custody by courts of competent jurisdiction;

- Production and reproduction of inmates to courts when required;

- Identification of the cause(s) of their convicts and anti-social behaviour;

- engaging inmates in reformative therapies and

- Running prison farm and vocational industries for the purpose of training prisoners in modern farming and skills acquisition.lv

The Prisons Service generates revenue in the process.lvi From the above, it can be deduced that the roles and functions of the Prison Service basically can be delineated into three: custodian, rehabilitative and reformative functions. A vivid description of the functions of prisons is captured in the words: first, 'penitentiary' (the place where one becomes penitent or remorseful); secondly, 'correctional institution' (a place where one is corrected) and thirdly, reformatory (a place where one is reformed and changed for better). ${ }^{\text {lvii }}$

At any rate, the extent to which these can be achieved has been a subject of controversy over the years. A glossary looks at the numerous prisoners that go in and out of the prisons in Nigeria shows that the prison system has not been able to live up to its expected role in the Nigeria Criminal Justice System.

\subsection{Causes of Recidivism in Nigeria}

\subsubsection{Lack of Categorization in Admission of Prisoners}

Putting adult and young people together in the prison cells is a common phenomenon in the Nigerian Prisons. This makes the children to be exposed to criminal lifestyle that can give rise to recidivism particularly among young prisoners. Likewise, all prisoners are housed in the same facility not minding their criminal records. This often times results in a situation where prisoners on civil cases or awaiting trial inmates who are in prison custody due to the fact that they cannot meet bail conditions, get in contact with hardened criminals and become initiated. This situation is unlawful as it runs contrary to the provisions of the United Nations Standard Minimum Rules for the Treatment of Prisoners. The international instrument in which Nigeria is a member state provides as follows:

The different categories of prisoners shall be kept in separate institutions or parts of institutions taking account of their sex, age, criminal record, the legal reason for their detention and the necessities of their treatment. Thus,

- Men and women shall so far as possible be detained in separate institutions; in an institution which receives both men and women, the whole of the premises allocated to women shall be entirely separate;

- Untried prisoners shall be kept separate from convicted prisoners;

- Persons imprisoned for debt and other civil prisoners shall be kept separate from persons imprisoned by reason of a criminal offence;

- Young prisoners shall be kept separate from adults. ${ }^{\text {lviii }}$

\subsubsection{Overcrowding/Poor Living Condition of Prisoners}

In recent times, Nigeria's prisons have witnessed extraordinary growth in the admission of prison inmates. The rate at which accused persons are pumping into the prison is alarming.lix Among the myriad of problems faced by the Nigerian Prisons is that of over-congestion, Inmates are being kept in prison custody beyond the capacity at which most prisons were built for. ${ }^{1 \times} \mathrm{A}$ previous research revealed that most prisons in Nigeria today were built before 1950 during the colonial era (over seventy years), and most, if not all, of those buildings are still used as prisons today despite being dilapidated and totally inadequate to meet the needs of contemporary prisons. ${ }^{\text {lxi }}$ The prison congestion has been causing inadequacies in essential needs for the inmates. Food (both in quality and quantity), a safe and secure environment, proper sanitation, water availability, provision of toilet facilities etc. have become life-threatening issues in the Nigerian Prisons. In that case, several prison inmates now have to sleep on the bare floor while many shares single bed. Disease outbreak due to pollution and unhygienic environment is a common occurrence in the Nigerian Prisons. The pain and suffering being experienced by prisoners inside Nigerian Prisons are untold and without measure. Considering the conditions of the prison, being sentenced to a term of imprisonment in Nigeria is akin to imposing the death sentence. All this hardened the criminal rather than reforming them. This precarious situation most often results in the death of inmates while the surviving ones are forced to become hardened criminals and go back to crime after release.

\subsubsection{Lack of Effective Vocational Training}

Vocational training is an act of engaging inmates with some work that can help them while in prison, and also as a means of sustenance after serving a jail term. Acquiring vocational skills while in prison undoubtedly helps prisoners when they are back in the society. This is because, if they are not gainfully employed after the expiration of their terms of imprisonment, recidivism is inevitable. 


\subsubsection{Lack of Aftercare Services}

Recidivism is also caused by the inability of the Nigeria Prison Service to provide tools and funds for the discharged inmates to start their own trades. Besides, the prison system cannot even afford to pay the transport fare of the vast majority of discharged inmates on the day of discharge in most cases. ${ }^{\text {Ixi }}$ It is quite unfortunate that what we have in Nigeria prison today is from reformation to deformation.

\subsubsection{Lack of Reintegration Support Programs}

Reintegration is often understood as the support given to offenders during their reentry into the society following imprisonment. A complete crime prevention program usually involves effective measures to prevent recidivism and put an end to repeat offenders. Offenders released from confinement face a multiplicity of challenges that may impede their ability to become law-abiding citizens. After release, there is usually no follow up of prisoners in line with international best practices. This is lacking in Nigerian Prisons, thereby giving rise to recidivism.

\subsection{Consequences of Recidivism in the Nigerian Prisons}

\subsubsection{Recidivism Jeopardizes Public Safety}

Recidivism victims contribute to crime in the society because of the experience they face while in prison. The implication is that imperative reducing recidivism is a public safety. ${ }^{\mid x i i}$

\subsubsection{Recidivism Wastes Government Fund}

Recidivism indicate that correctional facilities are failing to equip prisoners with tools for successful re-entry thereby shortchanging the fund meant for the welfare of prisoners.

\subsection{Review of the Prison Act as an Antidote to Recidivism in the Nigerian Prisons}

One of the criteria and measures for judging the effectiveness of the prison system and its reformative proficiency is the number of inmates who remain outside the prison wall after finishing their jail terms. ${ }^{\text {lxiv }}$ It is evident that a lot of people released from prison in Nigeria usually find their way back to it.

The current Nigerian Prison Act is outdated, unable to define the purpose of imprisonment and equally silent on the crucial service of reformation or rehabilitation. The Act focuses on retributive/punitive aspect of imprisonment, to the near total neglect of its rehabilitative/reformative demands. Consequently, the Nigerian prison system is witnessing a high rate of relapse of criminal/antisocial behaviour (recidivism) and recycling of un-regenerated convicts. Additionally, the prisons Act makes provision for vocational training for convicted criminals without considering the awaiting trial inmates. In my own opinion, this is a fundamental error as the awaiting trial inmates constitute the largest percentage of the inmates in the Nigerian Prisons. It is my opinion that a review of the Nigerian Prison Act to make provisions for reformation or rehabilitation and vocational training for the awaiting trial inmates is an antidote to recidivism in the Nigerian Prisons.

\section{Conclusion and Recommendations}

In conclusion, the enormous increase on recidivism is clear evidence that prisons in Nigeria are not what they are supposed to be; in a situation where two out of three prisoners released from the prisons often find their way back there within a short time of their release.lxv For example, recently, a 41-year-old and seven-time convict, Emmanuel Oyewumi was arrested by Rapid Response Squad of the Lagos State Police, Ojodu Berger Area of Lagos. While pleading for leniency, he admitted that he had been imprisoned three different times in the year 2016 and in totality; he had been in and out of prison seven times. ${ }^{\mathrm{kxv}}$ Hence, the problem of recidivism is a challenge to the practicality and feasibility of rehabilitation programs in Nigerian prisons. In view of this, there is the need to delve into making specific recommendations that may help in reducing recidivism in Nigerian Prisons as stated below.

In view of the fact that the high rate of recidivism in Nigeria prisons is bullet proof evidence that the correctional institution is ineffective in rehabilitating the offenders, there is the need to curb the menace in the Nigerian prison system by making educational and vocational programs more accessible to inmates through increasing the capacity and removing barriers. Effective measures that will guarantee this program must be put in place as this will go a long way to reduce the high rate of recidivism in the Nigerian society. The positive effect of this is that high enrollment into these programs would improve the employability of participants upon release into the society. Provisions of educational and vocational programs have been established to be leading recidivism-control strategies. Additionally, I hereby call for review of the Nigerian Prison Act to unambiguously capture the crucial service of reformation or rehabilitation and make provision for vocational training not only for the convicted criminals but also for the awaiting trial inmates.

Government should adequately fund Nigerian Prisons by renovating dilapidating structures and build more that will adequately take care of prisoners' population. Adequate funding should make provision for beds, food (both in quality and quantity), water, toilet and health facilities with adequate personnel. This will guarantee a safe and secure environment for inmates and prevents unhygienic condition, pollution and poor sanitation that can bring about loss of life or subjecting prisoners to inhuman treatment. Most importantly, government must wake up to its responsibility if universality of human right is to be sustained and ensure that that correctional facilities have the resources to rehabilitate incarcerated individuals for it is a precursor public safety. There must be political will by government to comply with and implement the provisions of the international instruments it entered into, which guarantee the rights of prisoners if prisons in Nigeria are to achieve their expected goals. 


\section{References}

i. Black Law Dictionary, 6th Centennial Edition (1891 - 1991)

ii. Otu M Sorochi, 'Analysis of the Causes and Effects of Recidivism in the Nigerian Prison System'Vol, 10. IJDMR.2015

iii. Tosin T Olonisakin, Adedeji J Ogunleye and Sulaiman O Adebayo, 'The Nigeria Criminal Justice System and its Effectiveness in Criminal behaviour Control: A Social-Psychological Analysis' Vol, 22.IJHS 2017

iv. Larry J Siegel and John L Worrall, Essentials of Criminal Justice Centage learning 2016.

v. Peter 0 Nwankwo, Criminal Justice in the Pre-Colonial, Colonial, and Post-Colonial Eras an Application of the Colonial Model to Changes in the Severity of Punishment in the Nigerian Law University Press of America 2010.

vi. John Domingo Inyang and Mcdonald Simon Awakessien, 'An Investigation on the application of Criminal Justice Procedure and its Impact on Crime Factors in AkwaIbom State, Nigeria' (2014) 4 IJHSS 214, 215.

vii. Smart E Otu, 'Criminals and Criminal Justice Administration in Nigeria: How Just, Fair and Dignifying is the System?' in GMT EmezueInge Kosch and Maurice Kangel, Justice and Human Dignity in Africa Lulu com 2014.

viii. Okwendi Joseph Solomon and Richard Nwankwoala, 'The role of restorative justice in complementing the justice system and restoring community values in Nigeria' (2014) 2 AJ HS126, 126.

ix. Black's Law Dictionary7thedn. West Publishing Co 1999 page 1276.

x. Blantine's Law Dictionary (3rd edn., The Lawyers Cooperative Publishing Co 1969) 1065; Adeola

xi. Shobola and Taiwo 0 Ajeigbe, 'Inmates Incarceration and Family Support as Precursors of Prison Recidivism In Nigeria' (2015)11 European Scientific Journal 492, 492

xii. http://punchng.com/dont-want-go-prison-eighth-time-suspect/accessed 3 July 2017

Ph.D. (North - West University, South Africa), LL.M (Ife), LL. B (Hons), B.L., Lecturer, Faculty of Law, Adekunle Ajasin University, Akungba-Akoko, Ondo State, Nigeria. Email: rokeju@yahoo.com, ibironke.kekere@aaua.edu.ng Mobile: +234(0)7061048574.

iOtu M Sorochi, Analysis of the Causes and Effects of Recidivism in the Nigerian Prison System (2015)10. International Journal of Development of Management Review 136,136.

iiTosin T Olonisakin, Adedeji J Ogunleye and Sulaiman O Adebayo, "The Nigeria Criminal Justice System and its Effectiveness in Criminal behaviour Control: A Social-Psychological Analysis' (2017) 22 Journal of Humanities and Social Science 33, 34

iii Larry J Siegel and John L Worrall, Essentials of Criminal Justice (10 ${ }^{\text {th }}$ edn, Cengage learning 2016) 9.

iv Peter O Nwankwo, Criminal Justice in the Pre-Colonial, Colonial, and Post-Colonial Eras an Application of the Colonial Model to Changes in the Severity of Punishment in the Nigerian Law (University Press of America 2010) 5.

vIbid; Criminal justice agencies are the main actors in the fight against crime; the police are responsible for detecting crime and apprehending people who violate the criminal law the courts decide guilt or innocence and sentence those who are convicted or those who plead guilty, and the prisons or correctional institutions carry out the sentence of the court and rehabilitate criminals.

Criminal justice can therefore be seen as a legal process, which involves the procedure of processing the person accused of committing crime from arrest to the final disposal of the case. See John Domingo Inyang and McDonald Simon Awakessien, 'An Investigation on the application of Criminal Justice Procedure and its Impact on Crime Factors in Akwalbom State, Nigeria' (2014) 4 International Journal of Humanities and Social Science 214, 215.

viSmart E Otu, 'Criminals and Criminal Justice Administration in Nigeria: How Just, Fair and Dignifying is the System?' inGMT Emezuelnge Kosch and Maurice Kangel, Justice and Human Dignity in Africa (Lulu com 2014)144.

viiOkwendi Joseph Solomon and Richard Nwankwoala, "The role of restorative justice in complementing the justice system and restoring community values in Nigeria' (2014) 2 Asian Journal of Humanities and Social Sciences 126, 126.

viii Black's Law Dictionary (7thedn. West Publishing Co 1999) 1276.

ixBlantine's Law Dictionary (3 $3^{\text {rd }}$ edn., The Lawyers Cooperative Publishing Co 1969) 1065; AdeolaShobola and Taiwo O Ajeigbe, 'Inmates Incarceration and Family Support as Precursors of Prison Recidivism in Nigeria' (2015)11 European Scientific Journal 492, 492.

xJoycelyn M Polluck, Prisons: Today and Tomorrow (Jones \& Bartlett Learning 1997) 202; McGuire, Offender Rehabilitation and Treatment: Effective Programmes and Policies to Reduce Re-offending (John Wiley \& Sons, 2003)135.

xiArjanBlokland and Victor van der Geest, The Routledge International Handbook of Life-Course Criminology (Taylor \& Francis 2017 ) 413.

xiiSchneider, Crime Prevention: Theory and Practice, Second Edition (CRC Press, 2014) 209.

xiiiMary Stohr, Anthony Walsh and Craig Hemmens, Corrections: A Text/Reader (2 $2^{\text {nd }}$ edn, SAGE Publications 2012) 439.

xivRobert D Hanser, Introduction to Corrections (SAGE 2012) 418.

xvSorochi, (n 1) 136; James Vadackumchery, Crime, Police, and Correction (APH Publishing 2000) 104.

xviHenry Campbell, Black's Law Dictionary (6th edn, Centennial Edition 1891-1991) 1194.

xvii Prisons Act Cap P29 LFN 2004, Section 19.

xviii Ibid Section 2(1), (2) (a) \& (b).

xixPaul Bahannan, Justice and Judgement among the Tivs (Oxford University Press 1957) 67- 68.

xxRey, Crime: An Analytical Appraisal, Volume 3 (Taylor \& Francis 2003) 66.

xxi Laurier Roderigue, The Pursuit of Wisdom (Exposition Press 1984) 122.

xxii Lloyd W McCorkle and Richard Korn, 'Resocialization within walls' (1954) 293 The Annals of the American Academy of Political and Social Science 88, 88.

xxiii Bryan A Gayner, Black's Law Dictionary, (8 ${ }^{\text {th }}$ edn, West Publishing Co 2004) 1232.

xxiv Prisons Act (n 17) Section 19.

xxv Ibid.

xxvi See generally Michael C Ogwezzy, 'From Reformation to Deformation: An Approach Towards Sustainable Development of the defective Prison System in Nigeria' (2011) 13 Journal of Sustainable Development in Africa 269; Anne Amuche Obiora, Restorative Justice and Crime Prevention:Antidote for Prison Congestion and Improvement of Prison Condition in Nigeria (Cambridge Scholars Publishing 2014); C hukwuma Innocent, "The Legal Structure of the Police and Human Rights in Nigeria'(1997)14 Third World Legal Studies 41, 49; The Court affirmed the view that a person becomes a prisoner from the date of his or her first admission into Prison custody. In effect, awaiting trial inmates (ATM) are prisoners because they are normally admitted pursuant to a court order and steps in regulation 2 of the Prisoners Act are observed before they are taken into custody which provides that no person may be admitted into a Prison unless by a warrant of arrest, a warrant or order of detention or a warrant of conviction or commitment and the superintendent shall verify that the person is the person named in the warrant book or order, that the crime, sentence and date of conviction are recorded therein and that the warrant or order bears the signature of the proper authority. See Edmound Okoro and Ords v Minister of Internal Affairs Suit No FHC/EN/CP/102/2000.

xxvii Criminal Procedure Act Cap 41 L F N 2004, Section 377; Lilian Akhirome-Omonfuegbe, 'Law in social context' inChijioke C Ohuruogu and Okechukwu Timothy Umahi (eds), Nigerian Legal Methods (Cambridge Scholars Publishing 2013) 24.

xxviiiRichad J Perry, From Time Immemorial: Indigenous Peoples and State Systems (University of Texas Press 2010) 106. 


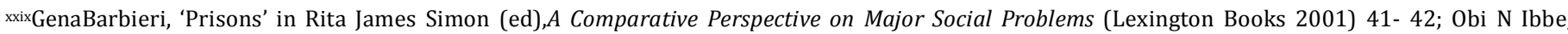
'United Nation Provisions for Punishment of Offenders vis -a-vis Punishment for Offenders in History' in Obi N Ebbe (ed), Comparative and International Criminal Justice Systems: Policing, Judiciary, and Corrections, ( $3^{\text {rd }}$ CRC Press 2013) 244; And whosoever will not do the law of thy God, and the law of the king, let the judgement be executed speedily upon him, whether it be unto death, or to banishment or to confiscation of goods, or to imprisonment. See Ezra Chapter 7 verses 26.

xxx Ibid 41.

xxxi The Holy Bible Genesis chapter 39 verses 1, King James Version.

xxxii The Holy Bible Genesis chapter 39 verses 19, King James Version

xxxii The Holy Bible Genesis chapter 39 verses 20 King James Version.

xxxiv The Holy Bible Genesis chapter 39 verses 1-23 King James Version; See generally Ojo Tajudeen Ibraheem, 'Behind the Prison Walls: Rights or No Rights?' (2013) 2 International Journal of Innovative Research \& Development 779, 780.

xxxv Nathan Jun, Anarchism and Political Modernity Contemporary Anarchist Studies (A\&C Black 2011) 163; Sotirios Frantzanas, 'Nathan Jun, Anarchism and Political Modernity' (2013) 21 Anarchist Studies 108, 163.

xxxi Ovo Catherine Imoedemhe, The Complimentary Regime of the International Criminal Court: National Implementation in Africa (Springer 2016) 165; Otu (n 6) 153.

xxxvii Ibraheem (n 34).

xxxviiiEmeka E Obioha, 'Challenges and Reforms in the Nigerian Prisons System' (2011) 27 Journal of Social Science 95, 96.

xxxix Imprisonment has been a form of practice even before the emergence of colonial rule in Nigeria. According to Okunola et al., They affirm the assertion that in the Northern Nigeria, a Traditional Legal System including prison was already in place before the British imperialism. Equally, in South Western Nigeria as well as other parts of the country, prison was part of political and legal system before and during colonialism. See Rashidi Akanji Okunola, Adeyinka Abideen Aderinto and Atere Adewole Akinyemi. The Prison as a Social System: Current and Perspectives in Sociology (Malthouse Press 2002) 319-334; Awe Bolanle, 'History of the Prison System in Nigeria' in Teslim Olawale Elias (ed), The Prison System in Nigeria (University of Lagos Press 1968) 95; Viviane Saleh-Hanna and Criminal Justice in Nigeria' in :metsyS laneP eht fo noitulovE nA',Chukwura UmeViviane Saleh-Hanna (ed), Colonial Systems of Control: Criminal Justice in Nigeria (University of Ottawa Press 2008) 55.

xl See generally Adetami Oluseyi, A Reformatory Approach to the Criminal Justice System in Nigeria (Crest Publishers 2013 ) 130.

xliTeslimOlawale Elias, 'The Prison System in Nigeria' (Prison System Conference July 1968).

xlii Moses U Ikoh, 'The Nigerian Prison System and the Failure of Rehabilitation: An Examination of Incarceration Alternatives' (2011) 20 The Nigerian Academic Forum 1, 2; Kebreab Isaac Weldesellasie, 'The Development of Criminal Law and Justice in Africa from Pre-Colonial Rule to the Present Day' in Charles ChernorJalloh and Ilias Bantekas (eds),The International Criminal Court and Africa (Oxford University Press 2017 ) 248.

xliiilkoh (n 42).

xlivIkoh (n 42).

xlv Joseph Omodele Adewumi, Essentials of the Nigerian Corpus Juris (Alabi-Eyo\& Company 1998) 176.

xlviToyin Falola, 'Brigandage and piracy in nineteenth century Yorubaland' (1996) 12 Journal of the Historical Society of Nigeria 83, 105. This study offers insight into the organization of crime in different areas in the Yoruba hinterland before colonial rule.

xlvii Vivian and Ume (n 39)57.

xlviii Chukwu Chigozie Brown, Reforming Nigeria Prisoners (Lulu com 2012) 6; Elias (n 39).

xlix Ibid; Evolution of imprisonment in Nigeria<http://martinslibrary.blogspot.com/2014/05/evolution-of-imprisonment-in-nigeria.html>accessed 28 July 2017

'John A Arthur, 'Development of penal policy in British West Africa: Exploring the colonial dimension' (1991) 15 International Journal of Comparative and Applied Criminal Justice 187, 187-196.

lijombo Onyekachi, 'Problems and Prospects of Administration of Nigerian Prison: Need for Proper Rehabilitation of the Inmates in Nigeria Prisons' (2016) 5 Journal of Tourism and Hospitality 1, 1.

lii Elias (n 39) 57.

liii Ibid 58; Etannibi E 0 Alemika Criminal Victimization and Criminal Justice Administration in Nigeria in Etannibi E 0 Alemika (ed) Crime and Public Safety (CLEEN Foundation publisher 2014) 21.

liv Prison Act (n 17).

lv Viviane and Umen (n 39) 62 - 63; Andrew M Jefferson, 'Prison Officer training and practice in Nigeria contention, contradiction and re-imagining reform strategies' (2007) 9 Punishment \& Society 253, 258; PRAWA, Prisoner's Rehabilitation and Welfare Action 1999 (Nigerian Prison Service Annual report 2000).

lvi Prison Act Cap (n 17), Section 40; Alemika Etannibi 0 Criminal Victimization and Criminal Justice Administration in Nigeria in Etannibi E 0 Alemika (ed), Crime and Public Safety (CLEEN Foundation publisher 2014) 21; Teslim Olawale Elias, The Prison System in Nigeria (University of Lagos Press 1964) 58.

lviiChukwu Chigozie Brown, Reforming Nigeria Prisoners (Lulu com 2012) 65; Ogadimma Chukwubueze Arisukwu, Adejumo Yinka Philip and Festus Femi Asamu, 'Causes and Effects of Violence in Nigerian Prisons' (2015) 1 Journal of Social Sciences and Humanities 368, 369; Chikwe Agbakwuru and Emi Maria Ibe-Godfrey, 'Correlates of Coping with the Challenges of Incarceration Among Nigerian Prison Inmates' (2017) 5 British Journal of Education 69, 70.

lviii United Nations Standard Minimum Rules for the Treatment of Prisoners (the Nelson Mandela Rules) United Nation General Assembly Resolution 70/175 U.N.GAOR, $70^{\text {th }}$ Session, $80^{\text {th }}$ meetings, U.N.Doc, A/RES/70/175 (2015), Rule 8 (a) to (d). (the Mandela Rules) Adopted by the First United Nations Congress on the Prevention of Crime and the Treatment of Offenders, held at Geneva in 1955, and approved by the Economic and Social Council by its resolutions 663 C (XXIV) of 31 July 1957 and 2076 (LXII) of 13 May 1977, Resolution A/RES/70/175 it was adopted by the general Assembly of the United Nations on 17 December 2015. It was named in honour of the late President of South Africa, Nelson Mandela who spent 27 years in prisons in the course of his struggle for democracy and promotion of culture of peace. Although not legally binding, the Nelson Mandela Rules provides guidelines for domestic law for citizens held in prison and other forms of custody. They have been of great importance and a reference point for relevant national legislation as well as of practical guidance for prisons management

lix Andrew A Ovienloba, Crimes and Criminal Justice in Nigeria since Independence: The way Forward (JDPC 2000$) 25$.

kxee generally Awopetu Ronke Grace, 'An Assessment of Prison Overcrowding in Nigeria: Implications for Rehabilitation, Reformation and Reintegration of Inmates.' (2014) 19Journal of Humanities and Social Science 21, 21.

lxín Sam Souryal, Ethics in Criminal Justice: In Search of the Truth (Routledge 2014) 419.

lxiilbraheem (n 39) 792; Daniel P Mears and Joshua C Cochran, Prisoner Reentry in the Era of Mass Incarceration (Sage Publication 2014).

lxiii Peter R Jones, 'The risk of recidivism: Evaluating the public safety implications of a community corrections program' (1991) 19 Journal of Criminal Justice System 49, 49.

lxivOjoTajudeen Ibraheem (n 39) 792.

lxvFolarin Samson., 'I don't want to go to the Prison the Eighth Time' The Punch Newspaper (Nigeria) 10 October 2016, http://punchng.com/dont-wantgo-prison-eighth-time-suspect/accessed 3 July 2017.

lxvi Ibid. 